\title{
The Effect of Motivation, Training, and Communication on the Interest in Becoming a Member of PKK in the Bandulan Village
}

\author{
Sudjilah $^{1^{*}} \quad$ Eny Rachmawati ${ }^{2}$ \\ 1.Sekolah Tinggi Ilmu Ekonomi Indonesia Malang \\ 2.Universitas Mayjen. Sungkono Mojokerto
}

\begin{abstract}
The issue of empowering woman and children is the low participation and discrimination against woman. The other issue is gap of politic participation the woman causes inequality social cultural structure and religious that are gender biased. This study to examine the effect of motivation, training, and communication variables have a positive and significant effect on the interesting becoming a member of the PKK. This research is an Explanatory Research. Method of collecting data with in depth interviews, documentation, observation of the PKK's members. Data analysis is done by quantitative and was designed using quantitative methods. Research sample is 150 respondents, data analysis is done by quantitative methods and this research analysis uses SEM with AMOS software version 22. The result shows that motivation, training and communication have a positive and significant effect on the interest in becoming a member of PKK. The research implications, PKK as a community organization is a place for women to take part in development activities. The women are not limited to be a companion of husband, but, they're empowered as member of a community that have the same right. The empowerment is done through the formation of motivation, training and communication. The limitation of the research is limited time because it coincides with the working days.
\end{abstract}

Keywords: Motivation, Training, Communication, Interest

DOI: $10.7176 / \mathrm{IKM} / 9-5-02$

Publication date:May $31^{\text {st }} 2019$

\section{Introduction}

The role of woman as partner of husband couldn't be underestimated. There is no one anymore an adage that states "suwargo nunut neraka katut" that intended for Indonesian woman. The woman must be empowered. The government gives woman's place of existence with builder the minister of women's empowerment and gives quota as much as 30\% from parliamentarian in Indonesia. Quota of 30\%, even though it gives rise to pros and cons about nominal value of the number. However at least the women have obtained place to express their gaits as partner of husband. The role of wife as partner of husband also written in RPJMN 2004-2009 chapter 12 with the topic: Improving the quality and role of women and the welfare and protection of children (RPJMN 20042009:104). The fundamental problem in the development of empowerment women and children that happens all this time is low participation of women and children in development. Besides, there's still various forms of discrimination toward the women. The other problem include disparity in women's political participation that sourced from inequality of the socio-cultural structure of the community with fulfilled of interpretation of translations of religious teachings that are gender biased. By giving that freedom space, then, the government gives place at the basic level of the closest social level in the community that is organization of family welfare empowerment or better known with the name PKK, which is the government's program in order to empowering community especially through empowerment of family welfare. Prosperous family certainly is the part or foundation of welfare Indonesian community comprehensively. Failure or and success of empowerment of organizational community PKK are reflection from failure and or success of Indonesian family.

Specifically, the gait of this empowerment and welfare organization is expressed in ten (10) of main program of family empowerment and welfare. The main program of family empowerment and welfare involves: 1. Appreciation and Practice Pancasila, 2. Cooperation, 3. Food, 4. Clothing, 5. Housing and Household Governance, 6. Education and Skills, 7. Health, 8. Development of Cooperative Life, 9. Environmental Sustainability, 10. Healthy Planning. The ten of the main program of family empowerment and welfare if implemented consistently, will have a positive impact and significant toward welfare of Indonesian family. In fact, in the field unlike what the government planned, because in the Bandulan village suspected degradation of interest in community members to become the one member of PKK. The degradation from lack of motivation from the PKK's movers which is too stagnant in order to implement ten (10) of main program. Moreover, communication skills play a key role in order to move the community to become PKK members. Regeneration work enthusiasm, application strategy and leadership style that with local and global demands and based on the spirit to move forward, then the suppression about the importance of managing human resources has expressed the need for the application of HR concepts and theories in the life of public organization (Sulistyani dan Rosidah;2003:7). Refers to background, formulation in research are;

1. Whether the motivation variable has a positive and significant effect on the interest in becoming a PKK 
member?

2. Whether the training variable has a positive and significant effect on the interest in becoming a PKK member?

3. Whether the communication variable has a positive and significant effect on the interest in becoming a PKK member?

\subsection{Motivation}

Human resources are the most important elements. Continues and harmonious relationship maintenance with work partners in an organization is something that couldn't be avoided. How a leader could ensconce in the middle of organization members as sharpener, affectionate and caregiver. Realize that principle, a leader obligatory to be able in motivate the organization he leads. Motivation for organization members to attend training while communicating the will of the leader to organization members also need skills and own art to applied to organization members. Motivation is a process to try to influence someone to do something we want (Martoyo;1986:145) Abdurrahim (1990:38) said that motivation is excite the workers in such a way, so they passionately willing to do assignments to improve quality and productivity of company or institution. Complement the understanding of motivation, Sinungan $(1995 ; 134)$ Said that motivation is a mental state and a mental attitude that provides energy to encourage activities or movements and leads or channels behavior towards the achievement of needs that provide satisfaction or reduce imbalances. The workers in the production process are as humans (individuals), who have their identification among others behavior, needs, desires, ideals, habits formed by their original state and environmental conditions and experiences of the worker himself. The motivation of workers and employers is different because of differences in interests. Need to be created in the same direction to achieve common goals in the context of business continuity abd calm work. So that the goals of both parties could be achieved.

\subsection{Training}

Training is also a planned process for changing attitudes, knowledge or behavioral skills or several activities (Chusway;2000:26). This is different from education which gives certain subjects in general. Training is intended, so that the work situation, individuals can develop its ability to meet the needs of the workforce in the organization now and in the future. From that understanding, training is needed to improve the mastery and skills of various techniques for implementation of certain jobs within a certain period. Training is the preparation of employees to do work that is currently and will be done. Training could be done with off the job and on the job training. Off the job training is form of training that could be in form of courses, role playing or simulation, whereas on the job training is training with practical method in the work of employees in the form of rotation, or coaching. In principle, training is a process to help workers in order to master skills specifically or help to reduce limitations in carrying out work. The focus of the activity is to improve work ability in meeting the needs of effective work demands in the present or in the future (Nawawi;1998:43)

\subsection{Communication}

Arni Muhammad (2000:2) stated the meant of communication is a process to give signal according to certain rules. So that with this way, a system could be built, maintained, and changed. Whereas Bartol and Martin interpreted, communication as exchange between humans with the aim of getting the same understanding (2000:2001). To complete the understanding of communication, Davis Mangkunegara (2000:145) said; communication is the transfer of information and understanding from one person to another person. Referring to those various opinions, communication is an information delivery activity that has values, meanings, and intentions from one of the parties to the other party.

\subsection{Interest}

Interest is strong tendency of subject to feel interested with field of study or certain subject matter and feel pleased to learn the material provided and studied or can be told that interest is everything related to desire, will, and joy (Kamisa;1997:370). Interest could be generated in 2 ways, those are: 1 . Arouse a need, for instance the need to appreciate beauty, get awards etc. 2. Connect with past experiences give chances to get good results, nothing success like success or knowing the success that the individual has because success will lead to satisfaction. With that understanding, that interest could be said as a mental state that produces directed response to a situation or object that is pleasant and give satisfaction to someone. Therefore, interest could lead to pleasure and is and attitude that shows a readiness to do if there is a stimulus according to one's mental state.

\subsection{PKK Organization}

The National Development could be realized, if on the one hand there are adequate facilities and public services, and on the other hand there are residents and communities who consciously participate in order to realize the 
welfare of the sovereign nation and state. PKK is a women organization at the grass roots. Which formed since the New Order era precisely in 1961. At first, at the beginning if its formation, PKK is abbreviation from Pembinaan Kesejahteraan Keluarga (Family Welfare Development). Development is typical political language of New Order era to state direction and control, based on the interests of national security to secure development. Hypothesis

1. Motivation variables have a positive and significant effect on the interest in becoming a member of the PKK in the Bandulan village Malang.

2. Training Variables have a positive and significant effect on Interest in becoming members of the PKK in the Bandulan village Malang.

3. Variable Communication has a positive and significant effect on the interest in becoming a member of the PKK in the Bandulan village Malang.

4. Motivation variables have a positive and significant effect on the interest in becoming a member of the PKK in the Bandulan village Malang.

5. Training Variables have a positive and significant effect on Interest in becoming members of the PKK in the Bandulan village Malang.

6. Variable Communication has a positive and significant effect on the interest in becoming a member of the PKK in the Bandulan village Malang.

\section{Research Method}

This research is Explanatory research, namely research that explains the effect of causation between variables. The variables that will be examined consists of three independent variables, those are Motivation, Training, and Communication. And a dependent variable is Interest. (Ridwan;2004:58), scale measurement variable with Linkert scale. The testing is done by SEM (Structure Equation Modelling) statistical analysis with AMOS software helping. In the SEM is done 3 analysis activities at once in one analysis. Those are; 1). CFA Validity (Confirmatory factor Analysis), 2). Path Analysis, 3) Model Accuracy Test (Goodness of fit). The measurement of the level of validity and reliability. The research is using SEM with the AMOS 20 program package. SEM doesn't have one of the best statistical tests that could explain the predictive power of the model. As a replacement, some of GOF or Goodness of Fit Indices (GOFI) could be used together or combination. When compared with the criteria above the results of multivariate normality were obtained 10,417 >2,58 (Abnormal) based on the results of processed research data compared to these criteria, Then, could be concluded that data distribution is abnormal multivariate, But, in a central of Limit Central Theorem stated that assumption of normality isn't too critical for large samples (Solimun, 2002:79). The biggest distance of Mahalanobis is at observation 145 of 49,566, while the comparative value obtained is 194,883. The value of the Mahalanobis distance is smaller than the comparison value explains that there were no outliers in the observation sample observed,. So that the results could be continued for the next stage. Measurement model is model with the results of calculations based on calculation using the AMOS 20 program. The method used is Confirmatory Facto Analysis, where is with this tool will be known that the indicators really could explain a construct. The various tests that have been carried out. Then, the researches present the relation of the various variables and indicators studied which is presented in the form of a SEM diagram of the model. 


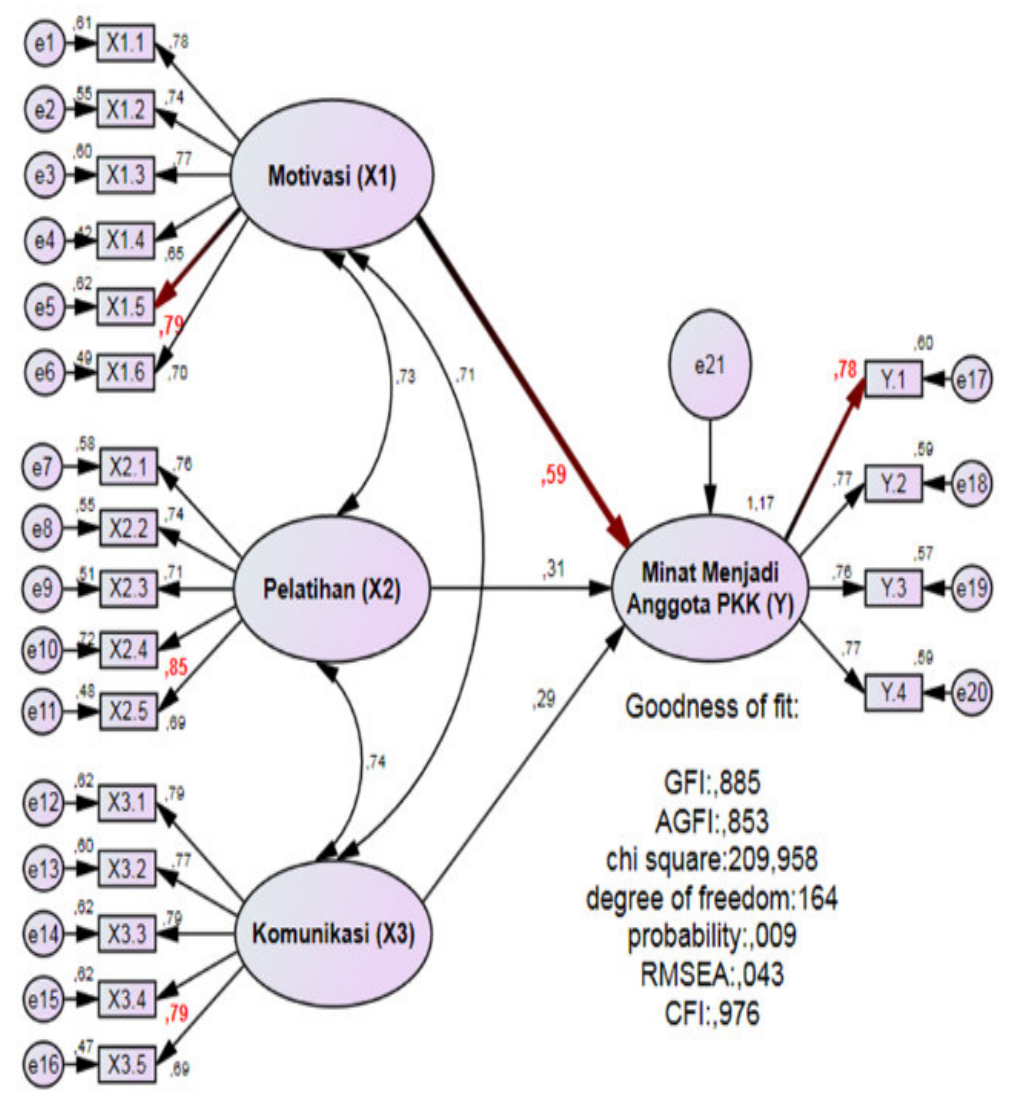

Figure 2. Diagram Model Modification of SEM

Source: statistic analysist results, 2015

\section{Result of Research and Discussion}

Sugiono (2009) said that the structural equation model (SEM) consists of two elements, namely the measurement model (outer model) and the structural model (Inner model). In one analysis, that's: 1) The Validity of CFA (Confirmatory Factor Analysis); 2) Path Analysis (Path Analysis); 3) model precision test (goodness of fit). Before discussing the results of the SEM analysis. It is necessary to conduct a deep assumption in which this involves the normal evaluation of the data and the outlier's evaluation. The processing of the data processing of the test assumption may be described as the following.

Model Punctually Goodness of Fit (GOF)

The first phase of this match is intended to refer to the public to fit degrees of fit or whether to fit (GOF) between the data with models. SEM does not have one of the best statistical training that can explain the strength that can explain the strength of the petunia model. In addition, several of the size of GOF or Goodness of Fit Indices (GOFI) can be used together or combination. Name of the GOF or GOFI sizes can be used as a basic evaluation of the model. The best known assess the model was a strong substantive theory. If the model is only shown or represent a strong substantive theory and though model has a very good model, somewhat difficult to assess the model. The overall test model is related to the analysis of the statics produced by the program, in it. It is AMOS 20. By using the size of the GOF statistic results, the series may be performed the overall model of the following models. 
Table 1: Evaluation of the structure matching model (before model modification).

\begin{tabular}{|c|c|c|c|}
\hline Goodness of fit Index & Cut of value & Result & Explanation \\
\hline Chi-Square / CMIN & $\begin{array}{l}<\text { Chi Table : Good fit } \\
>\text { Chi Table : Poor fit }\end{array}$ & 209,958 & Model Poor Fit \\
\hline P-value CMIN & $\begin{array}{l}>0,050: \text { Good fit } \\
<0,050: \text { Poor fit }\end{array}$ & 0,009 & Model Poor Fit \\
\hline $\mathrm{CMIN} / \mathrm{DF}$ & $\begin{array}{l}<2,000: \text { Good Fit } \\
<3,000: \text { Marginal Fit } \\
>3,000: \text { Poor Fit }\end{array}$ & 1,280 & Model Good fit \\
\hline RMSEA & $\begin{array}{l}<0,080: \text { Good fit } \\
<0,100: \text { Marginal Fit } \\
>0,100: \text { Poor fit }\end{array}$ & 0,043 & Model Good fit \\
\hline GFI & \multirow{4}{*}{$\begin{array}{l}>0,900: \text { Good fit } \\
>0,800: \text { Marginal fit } \\
<0,800: \text { Poor fit }\end{array}$} & 0,885 & Model Marginal fit \\
\hline AGFI & & 0,853 & Model Marginal fit \\
\hline TLI & & 0,973 & Model Good fit \\
\hline CFI & & 0,976 & Model Good fit \\
\hline
\end{tabular}

\section{Source: statistic analysist results, 2015}

Data Normality Test

In comparison to the criteria on the average, multivariate results are gained by 10,417 > 2,58 (not normal). According to the results of the research data in comparison to the criteria then it may be concluded that the distribution of data is abnormal from multivariate, but it the limit (Limit Central Theorem) suggests that the normal assumption is not too critical for a large sample (Solimun, 2002:79). The theorem of center limit is also mentioned that if the number of large sample $(n \geq 30)$ the statistics from those samples will be normal distribution (Walpole, 1995:214).

Assumption outliers

Outliers is an observation, where the characteristics are different from other observations. Outliers can be defeated. Extreme values that emerge from total scrutiny. One of the outliers evaluated was done by univariate defined the valued of boundaries that would be categorized as outliers by converting the value of research data into the standard 5 core and, the outliers approximating the multivariate by using the distance of Mahalanobis for each observation. The distance from Mahalanobis suggests the distance from an observation of the average of all variables in a multidimensional space. The criteria employee is based on chi-square's value at a degree of freedom (a degree of freedom) and at a certain level significance.

Table 2: The Top 5 Score of Mahalanobis Distance

\begin{tabular}{|c|c|c|c|}
\hline Sample (n) & $\begin{array}{l}\text { Mahala Nobis } \\
\text { d-squared }\end{array}$ & Critics Point & Explanation \\
\hline 145 & 49,566 & \multirow{5}{*}{$\begin{array}{lr}< & 194,883 \\
& (\text { Chi-Square Table pada Df: } 164)\end{array}$} & Outlier free \\
\hline 149 & 47,303 & & Outlier free \\
\hline 144 & 46,806 & & Outlier free \\
\hline 147 & 46,356 & & Outlier free \\
\hline 143 & 43,531 & & Outlier free \\
\hline
\end{tabular}

\section{Source: statistic analysist result, 2015}

Mahala Nobis's biggest range for 145 observation was 49.566, while the value of control was obtained in 194,883 . The mahala Nobis's smaller range value of the comparison explains that there are no outliers in the observable sample, so that the results can continue for the next phase.

Measurement Mode

Measurement models are models by reckoning using the programmed of AMOS 20. The method used of confirmation factor analysis, in which using the tools is well known the indicators of existing can explain a construction 
Table 3: Validity Evaluation and Reliability (Outer Model)

\begin{tabular}{|c|c|c|c|c|c|c|c|c|}
\hline \multirow{3}{*}{ Latent Variables } & \multirow{3}{*}{$\begin{array}{l}\text { Observer } \\
\text { Variable }\end{array}$} & Converg & idates & \multirow[b]{3}{*}{ 兰 } & \multirow{2}{*}{\multicolumn{2}{|c|}{$\begin{array}{l}\text { Discriminant } \\
\text { Validates } \\
(\text { AVE }>0,5=\text { Valid })\end{array}$}} & \multirow{2}{*}{\multicolumn{2}{|c|}{$\begin{array}{l}\text { Construct } \\
\text { Reliability } \\
(\mathrm{CR}>0,7) \\
\end{array}$}} \\
\hline & & \multicolumn{2}{|c|}{ (LF $>0,5=$ Valid $)$} & & & & & \\
\hline & & $\begin{array}{l}\text { Loading } \\
\text { Factors }\end{array}$ & Ket & & AVE & Summary & CR & Explanation \\
\hline \multirow{6}{*}{ Motivation (X1) } & $\mathrm{X} 1.1$ & 0,779 & Valid & 2 & \multirow{6}{*}{0,800} & \multirow{6}{*}{ Valid } & \multirow{6}{*}{0,953} & \multirow{6}{*}{ Reliable } \\
\hline & $\mathrm{X} 1.2$ & 0,744 & Valid & 4 & & & & \\
\hline & $\mathrm{X} 1.3$ & 0,772 & Valid & 3 & & & & \\
\hline & $\mathrm{X} 1.4$ & 0,650 & Valid & 6 & & & & \\
\hline & X1.5 & 0,789 & Valid & 1 & & & & \\
\hline & $\mathrm{X} 1.6$ & 0,701 & Valid & 5 & & & & \\
\hline \multirow{5}{*}{ Training (X2) } & $\mathrm{X} 2.1$ & 0,765 & Valid & 2 & \multirow{5}{*}{0,789} & \multirow{5}{*}{ Valid } & \multirow{5}{*}{0,867} & \multirow{5}{*}{ Reliable } \\
\hline & $\mathrm{X} 2.2$ & 0,740 & Valid & 3 & & & & \\
\hline & $\mathrm{X} 2.3$ & 0,711 & Valid & 4 & & & & \\
\hline & $\mathrm{X} 2.4$ & $\mathbf{0 , 8 5 1}$ & Valid & 1 & & & & \\
\hline & $\mathrm{X} 2.5$ & 0,691 & Valid & 5 & & & & \\
\hline \multirow{5}{*}{$\begin{array}{l}\text { Communication } \\
\text { (X3) }\end{array}$} & X3.1 & 0,787 & Valid & 2 & \multirow{5}{*}{0,805} & \multirow{5}{*}{ Valid } & \multirow{5}{*}{0,876} & \multirow{5}{*}{ Reliable } \\
\hline & X3.2 & 0,774 & Valid & 4 & & & & \\
\hline & X3.3 & 0,785 & Valid & 3 & & & & \\
\hline & X3.4 & 0,789 & Valid & 1 & & & & \\
\hline & X3.5 & 0,685 & Valid & 5 & & & & \\
\hline \multirow{4}{*}{$\begin{array}{l}\text { Becoming } \\
\text { Member of PKK } \\
\text { (Y) }\end{array}$} & Y.1 & 0,776 & Valid & 1 & \multirow{4}{*}{0,770} & \multirow{4}{*}{ Valid } & \multirow{4}{*}{0,940} & \multirow{4}{*}{ Reliable } \\
\hline & Y.2 & 0,768 & Valid & 2 & & & & \\
\hline & Y.3 & 0,755 & Valid & 4 & & & & \\
\hline & Y.4 & 0,768 & Valid & 2 & & & & \\
\hline
\end{tabular}

\section{Source: statistic analysist result, 2015}

Based on the markings at the outset it can indicate that all the value of loading factor $\geq 0.50$ (valid), and the value of an $A V E \geq 0,50$ (valid). Thus, it can be concluded that the validity of all the manifest variables in their Latin variables is good. However, the result of a reliability calculations suggests that all the value of a Reliability Construct $(\mathrm{CR}) \geq 0.70$ (reliable), then it can be concluded that all those latent variables have a good reliability. Structural mode (mode structural)

A causal relationship is stated to be insignificant if the value of critical ratio (C.R.) is between -1.96 and 1.96 in a significant proportion of 0.05 . With the help of AMOS 20's program application came an estimated value of economic model ratio presented in the following table:

Table 4: Estimate and Hypothetical test results

\begin{tabular}{|c|c|c|c|c|c|c|c|}
\hline \multicolumn{3}{|l|}{ Variables } & \multirow{2}{*}{$\mathbf{H}$} & \multirow{2}{*}{$\begin{array}{l}\text { Path } \\
\text { Coefficient }\end{array}$} & \multicolumn{2}{|c|}{$\begin{array}{l}\text { Hypothesis } \\
\text { Test }\end{array}$} & \multirow[t]{2}{*}{ Summary } \\
\hline $\begin{array}{l}\text { Exo } \\
\text { gen }\end{array}$ & $-->$ & Endo-gen & & & $\mathbf{C R}$ & $\begin{array}{l}P \\
\text { pvale }\end{array}$ & \\
\hline Motivation (X1) & $-->$ & $\begin{array}{l}\text { Interest becoming member of } \\
\text { PKK (Y) }\end{array}$ & $\mathbf{H}_{1}$ & 0,591 & 9,154 & 0,000 & Significant \\
\hline Training (X2) & $-->$ & $\begin{array}{l}\text { Interest becoming member of } \\
\text { PKK (Y) }\end{array}$ & $\mathbf{H}_{2}$ & 0,306 & 5,848 & 0,000 & Significant \\
\hline $\begin{array}{l}\text { Communication } \\
\text { (X3) }\end{array}$ & $-->$ & $\begin{array}{l}\text { Interest becoming member of } \\
\text { PKK (Y) }\end{array}$ & $\mathbf{H}_{3}$ & 0,294 & 5,779 & 0,000 & Significant \\
\hline
\end{tabular}

Source: statistical result, 2015

\section{Discussion of Research}

Hypothesis 1

Motivational variables in a positive and significant way affect the interest of being a member of the PKK in the sterility of an unfortunate complication. Motivation variable (X1) has an influence (line coefficient) on being a member of the PKK (Y) of 0.591, it is of positive value, with an c value of 9.154 and a p-value of 0 , with an indicator of best experience. Since the value of CR is in the range of -1.96 and 1.96 and the value of $p$-value $<$ 0.05 , the statistical hypothesis states $\mathrm{H} 1$ is acceptable, meaning motivation (X1) has a significant effect on the interest of being a member of the PKK (Y). It is in accordance with what synchro expressed $(1995 ; 134)$ says that motivation is the mental state and mental attitude of humans that gives energy, encourage activity or movement and direction or channel behavior toward fulfilling needs or dismissing imbalance. Whereas, according to gray in 
the Ferillian Prasetya, (2011:1), motivation is some process, internal, or external for an individual, which causes an attitude of enthusiasm and persistence, in carrying out certain activities. The findings of this study support theoretical studies. Training elicits a positive response from members of the PKK. They feel that training affects the ability of thought and motion movements and even has economic value for the family. In principle, the training is given according to 10 basic programs which is defined by the central government. Motivation and training are more likely to be received properly because they are coupled with a full network of two-way communication between the director and the rest of the PKK members. This study supports the results of research already conducted by Sharil, Trisakti Handayani, Sarsinto Rini and Radika Setyoaji reveals in 2010, which states that identifying strategies have been carried out by member of PKK, the lack of communication and information from the PKK for members will negative affect the interest of members of the PKK. The need for synergy through SKPD is a strategy used in managing activities. Any obstacles will be followed up with recommendations to the parties. The study also supports the study of Nina Rosa Riana, Sjamsiar Sjamsuddin, Ainulhayat 2011, which notes that the role of the PKK can move people motivated to be ever dynamic, changing things in more progressive direction. It also supports the results of the 2013 study carried out by Ramandita Shalbailiff, who stated that the officers played a major role in the motivation of the PKK administration.

Hyphothesis 2

Positive and significant variable of training centers on interest became a member of the PKK at the Bandulan village Malang. A variable of training (X2) has an influence (the coefficient line) towards the interest into a PPK (Y) of 0,306 , the influence was a positive, with the value of 5,848 and a p-worth of 0 to the best indicator is the performance. Because the value of the $\mathrm{CR}$ is at range - 1,96 and 1,96 as the value of the p-value $<0,05$, then statistical theorist states $\mathrm{H} 2$ received, meaning training (X2) positive and significant interest to interest becoming a member of PKK (Y). Thus, if the administrator wanted to increase the value of the development variable (X2) then statistical recommendations to the priority to become priority to be X2.4 indicator (performance). This finding supports the theory that the training is also planned to change the attitude, knowledge or conduct behavior through observation to achieve effective performance in activities or number of activities (Cushway;2000:26). The definition is that the training was needed to improve the possession and of the range of a specific work technique in each period. Training is preparation of employees to do both medium and will do. Training can be done off the job and on the job training. Off the job training is a training form that can be of course, role-playing or simulation, while on the job training is training with Practical methods of employee work were rotation, intern or coaching. In principle, training is a process that helps workers to master special skill or helps to reduce the limitations of performing the work. The focus of the activity was to increase the ability of work to meet the demands for effective work in the present and future (Nawawi;1998:43). It supports the 2010 Setyoaji reveals Radika research, which found that contributing factors or participation and interest of members of the PKK were high enough to be coupled with intense training. The results also support the study conducted by Nina Rosa Riana, Sjamsiar Sjamsudin in 2011. His research found that the role of the PKK can stir people up motivated to be ever dynamic, able to change things more advanced direction. The benefits are felt by the people. PKK empowerment through skill training can increase women's role in building to the millennium development goals to be achieved by 2015. It also empowers research conducted by Sarsinto Rini Putra of 2011, who stated that the PKK can be used to empower people's abilities through training to achieve the welfare of the family and community. Further, the results also support research by oxidizer Jatininghell, Listyaning, and Anik Andayani in 2014, which claimed that the PKK could be used as a meeting and communication and strengthening of PKK's function.

Hypothesis 3

Communication Variables are positively and significantly influence the Interest in becoming PKK members in Bandulan village Malang. The most significant components in the form of communication variable (X3) is x3.4 (it is easy) with loading the highest factor of 0,789 . Thus, if the management sector intends to increase the value of communications variable (X3) then the statistical recommendations of indicator need to become priority are X3.4 indicators (easily understood). The findings support the theoretical statement presented the Arni Muhammad (2000:2), which is referred to by communication is a process given signal according to certain rules so that, this is a system can be established, preserved and changed. Further, Bartol and Martin defined communications as interhuman exchanges gain the same understanding (2000:2001). Complemented the understanding of the communication, Davis Mangkunegara (2000:145) said: communication is transfer information and understanding from one person to another. Empirically, this study supported the research that was done by Rini Dorojati, M.S., Rr. Leslie Retno Angengingsih, Nuraini Dwi Astuti, M.P. 2010 who stated that communication and informational transmission would be positively significant to enhances the performance of a member of the PKK.

\section{Conclusion}

Variable motivations positively and significantly affect the interest of being a member of the PKK in an 
unfortunate disappearance, with the best experience indicator. Training variables in a positive and significant way affect the interest of being a member of the PKK in the sterility of an unfortunate complication. Your best indicator is performance. Variable communications are positive and significant to the interest of being a member of the PKK member in the hapless secrete with the best indicator is easily understood. The best indicator of forming a variable interest in members of forming a variable interest in members of PKK is being interested in performing duties. The structural model used can be used to make decisions for governments in giving special space to women.

\section{Implications}

Research results suggest that all free variegations have a positive and significant result in variable bound. Later years were required to be achieved, if could be upgraded. Factors that need to be hidden in the increased interest of interest in household and women are generally to become a PPK member in the Bandulan village, was a more intense communication that was more than a member of the other person and its chairmen and coaching its use of RT, RW to the Bandulan Village. In order to create a harmonious and conducive organizational cultural framework and contemplation as a teamwork either between members and administrators as well as the role as well as municipalities in the PKK 's recollections program. All governing PKK or the party for village and agencies for outer village concern for success and development as well as the advancement of PKK. It is required to link the local government support which continued to develop a development as well as the study of PKK 's program in the nearby village of Bandulan village Malang. It needs to link private roles such as CSR companies open to access to the PKK levels (PKK RW) so that programs can directly be perceived society. The city government established cooperation with entrepreneurs to give multiple percent of the benefits of the PKK 's movement at its basis.

\section{References}

Arni Muhammad.2000.Pelatihan dan Pengembangan Personalia di Perusahaan.Penerbit Bina Aksara.Bandung. Bartol dan Martin.200.Motivation and Training.Edisi Bahasa Indonesia Indonesia.Penerbit Tarsito Bandung. Bollen, Kenneth A., dan J. Scot Long (editors). (1993). Testing Structural Equation Model, Sage Publication Cushway.2000.Human Resource Management.Edisi 10.Penerbit Alfabeta.Jakarta

Davis Mangkunegara.2000.Mencapai Keunggulan Bersaing.Penerbit Alfabeta.jakarta.

Hasibuan.1999.Manajemen Personalia. Penerbit Jambatan Bandung.

Kamisa.1997.Kamus Lengkap Bahasa Indonesia.Penerbit Kartika Surabaya.

Mangkunegara,David.2000.Communicati-on and Tranformation.Penerbit Salemba.Jakarta.

Martoyo,Susilo.1986.Pengurus umberdaya manusia.BPFE.Yogyakarta.

Nawawi;1998.Pengelolaan Manajemen Sumber Daya Manusia.Penerbit Tursina.Bandung

Nina Rosa Riana, Sjamsiar Sjamsuddin, Ainul Hayat.2011.Peran PKK terhadap Perubahan dan Motivasi Masyarakat. Jurusan Administrasi Publik, Fakultas Ilmu Administrasi, Universitas Brwaijaya, Malang.

Oksiana Jatiningsih, Listyaningsih, dan Anik Andayani Penguatan Fungsi Edukasi Pkk: Pendidikan Gender Untuk Membangun Kehidupan Demokratis . Cakrawala Pendidikan, Februari 2014, Th. XXXIII, No. 1.p. 103-112

Pelaksanaan Peran Tim Penggerak Pemberdayaan Dan Kesejahteraan Keluarga (Pkk) Dalam Memberdayakan Perempuan (Studi tentang Program Pendidikan dan Keterampilan di Kecamatan Kaliori, Kabupaten Rembang) Jurnal Administrasi Publik (JAP), Vol. 2, No. 5, Hal. 851-856 | 851.

Prasetya Ferilian.Faktor-faktor yang Mempengaruhi Motivasi. Edisi 28 November,2011.Ferilian.blogspot.com download 12 September 2014.

Radika Wahyu Setyoaji. 2010. Dampak Program Kelompok Pemberdayaan PKK Terhadap Peningkatan Pemberdayaan Ekonomi Perempuan di Dusun Sosoran Desa Candimulyo Kecamaatan Kedu Kabupaten Temanggung

Rini Dorojati, M.S., Rr. Leslie Retno Angeningsih M.Sc., Ph.D., Dra. Nuraini Dwi Astuti, M.P.Strategi Pengelolaan Kegiatan Pkk Dalam Mewujudkan Masyarakat Sejahtera Berbasis Masyarakat Wilayah RW Di Kecamatan Kraton Dan Gondomanan Kota Yogyakarta. Jurnal Penelitian Volume Ii.Edisi tidak dicantumkan.

RPJMN 2004 - 2009. Peningkatan Kualitas kehidupan Dan Peran Perempuan Serta Kesejahteraan dan Perlindungan Anak.Jakarta.

Ramandita,Shalfiah.2013. Peran Pemberdayaan Dan Kesejahteraan Keluarga (Pkk) Dalam Mendukung Programprogram Pemerintah Kota Bontang.

Sarsinto Rini Putra.2011. Reposisi dan Refungsi PKK sebagai Upaya Untuk Pemberdayaan Masyarakat

Sinungan,Muchdarsyah.1995.Produktivitas Apa dan Bagaimana. Edisi Kedua.Cetakan Kelima.Penerbit Bumi Aksara.Jakarta.

Syahril,dkk,1999, Evaluasi keberhasilan program PKK dan kaitannya dengan Kehidupan Keluarga Pedesaan 
Karanganyar.

Solimun. 2002, Multivariate Analysis Structural Equation Modelling (SEM) Lisrel dan Amos. Fakultas MIPA, Universitas Brawijaya.

Sugiyono. 2009. Statistika untuk Penelitian, Bandung: Alfabeta

Sulistyani dan Rosidah. 2003.Pengurus Sumber Daya manusia.Yogyakarta.

Trisakti Handayani. 2009, Pemberdayaan Dan Kesejahteraan Keluarga (PKK) Di Kota Malang: Dalam Perspektif Kajian Budaya

Walpole, E. Ronald. 1995. Ilmu Pelung dan statistika untuk insinyur dan ilmuan, Edisi keempat. Penerbit ITB : Bandung. 